\title{
Harmonization of the Fire Severity in Standard Fire Resistance Test Furnaces
}

\author{
MOHAMED A. SULTAN and MICHAEL DENHAM \\ National Fire Laboratory \\ Institute for Research in Construction \\ National Research Council Canada \\ Ottawa, Ontario, Canada, K1A OR6
}

\begin{abstract}
This paper discusses a methodology for harmonizing the fire severity in fire resistance test furnaces. The presented methodology is based on the predicted results obtained from models that examined the effects of furnace depth, furnace lining material and type of fuel on the fire severity in fire resistance test furnaces using the CAN/ULC-S101, ASTM E119 and ISO 834 time-temperature relationships. Comparisons between the predicted and measured temperature distribution in a test specimen at $40 \mathrm{~mm}$ from the exposed side for floor furnaces lined with ceramic fibre insulation and insulating firebrick are provided. Results showed that the type of furnace lining material significantly affected the fire severity to the test specimen while the effects of furnace depth and type of fuel used in the furnace were minimal when the furnace was lined with ceramic fibre insulation. Recommendations to improve the reproducibility of the fire severity in fire resistance test furnaces for better harmonization between fire resistance test furnaces are provided.
\end{abstract}

KEYWORDS: Fire severity, fire resistance, furnace lining, furnace depth, castable refractory brick, ceramic fibre insulation, insulating firebrick, fireclay brick

\section{INTRODUCTION}

Fire severity in fire resistance test furnaces is a critical parameter in determining the fire resistance performance of specimens. It is assumed that different test furnaces will provide the same fire severity to the test specimens.

Cooke [1] carried out fire resistance tests in two gas-fired floor furnaces in the U.K. and in one oil-fired floor furnace in Germany to compare the fire resistance performance of specimens when the furnace was controlled by conventional thermocouples as required by the ISO 834 [2] standard and when the furnace was controlled by plate thermometers. Cooke concluded that, when a single plate thermometer located at the centre of the furnace, was used to control the furnaces, the differences in the fire severity to the test specimen produced by the three furnaces were markedly reduced compared to tests with conventional 
thermocouples. When the average of five plate thermometers was used to control the furnace, however, the differences in fire severity were not reduced.

Fire resistance test standards assume that, if a specimen is tested in one furnace and a similar specimen is tested in another furnace, the fire resistance performance will be similar. This assumption is questionable. In standard fire resistance tests, CAN/ULC-S101[3], ASTM E119 [4] and ISO 834 [2], the furnace is controlled by a specific time-temperature relationship with a specific type of thermocouple for measuring the furnace temperatures at nine locations (CAN/ULC-S101 specifies protected thermocouples, ASTM E119 specifies protected thermocouples with a 5 to 7.2 min time constant and ISO 834 specifies bare wire thermocouples). However, the furnace temperature is not the only parameter that controls the fire severity to the test specimen. Other parameters such as the furnace lining material, type of fuel used (liquid or gas) and depth of furnace may also affect the fire severity to the test specimen. These parameters are not specified in the present fire resistance standard test methods. Understanding how the design and operation of fire resistance furnaces affect the reproducibility of fire resistance test results has been designated a priority item by the ULC, ASTM and ISO Committees.

Some of the above-mentioned parameters which affect the fire severity in fire test furnaces were previously studied by Harmathy [5] and Sultan, et. al. [6] using the normalized heat load concept and by Sultan [7] using a castable refractory brick specimen. In this current paper, the effects of furnace depth, type of furnace lining material and the type of fuel used in fire test furnaces on the fire severity to castable refractory brick and lightweight concrete test specimens are investigated.

\section{THEORETICAL CONSIDERATIONS}

The mathematical models developed by Harmathy [5] and Sultan, et. al. [6] for the heat transmission in fire test furnaces were utilized in this study. The combined radiativeconvective heat transmission between the furnace hot gases and the specimen as well as the furnace walls, and radiative heat transmission between the specimen and furnace walls were considered. Because of the complexity of the models, only the governing equations are reproduced in this paper.

The analytical time-temperature relationships used in this study are as follows:

\section{CAN/ULC-S101 and ASTM E119}

$\mathrm{T}_{\mathrm{g}}=\mathrm{T}_{0}+750(1-\exp (-0.49 \sqrt{\mathrm{t}})+22.0 \sqrt{\mathrm{t}}$

2. ISO 834

$\mathrm{T}_{\mathrm{g}}=\mathrm{T}_{0}+345 \log _{10}(1+8 \mathrm{t})$

where $\mathrm{T}_{\mathrm{g}}$ is the furnace temperature $\left({ }^{\circ} \mathrm{C}\right), \mathrm{T}_{0}$ is the initial temperature $\left({ }^{\circ} \mathrm{C}\right)$ and $\mathrm{t}$ is the time (min).

The two equations (Equations (6) and (7) in Reference [5]) describing the radiative heat exchange between the test specimen and a furnace walls are:

$$
\begin{aligned}
& B_{1}^{j}-F_{11} \gamma_{11} B_{1}^{j}-F_{12} \gamma_{12} B_{2}^{j}-\varepsilon_{g 1} \sigma\left(T_{g}^{j}\right)^{4}+q_{r 1}^{j}=0 \\
& B_{2}^{j}-F_{21} \gamma_{21} B_{1}^{j}-F_{22} \gamma_{22} B_{2}^{j}-\varepsilon_{g 2} \sigma\left(T_{g}^{j}\right)^{4}+q_{r 2}^{j}=0
\end{aligned}
$$


where the superscript $\mathrm{j}$ indicates that the variables are at time $\mathrm{t}=\mathrm{j} \Delta \mathrm{t}$ and the subscripts 1 and 2 refer to the boundary surfaces of the specimen and the furnace walls, respectively. The other parameters are defined as follows: $\mathrm{B}_{1}$ and $\mathrm{B}_{2}$ are the radiative heat leaving Surfaces 1 and 2 , respectively; $F_{11}, F_{12}, F_{21}$ and $F_{22}$ are the configuration factors; $\gamma_{11}, \gamma_{12}, \gamma_{21}$ and $\gamma_{22}$ are the transmissivities of the furnace gas; $\varepsilon_{\mathrm{g} 1}$ and $\varepsilon_{\mathrm{g} 2}$ are the emissivities of the gas into Surfaces 1 and 2, respectively; $\mathrm{q}_{\mathrm{r} 1}$ and $\mathrm{q}_{\mathrm{r} 2}$ are the radiative heat absorbed by Surface 1 (specimen) and Surface 2 (furnace walls), respectively and $\sigma$ is the Stefan-Boltzmann constant.

The convective heat absorbed by the specimen $\mathrm{q}_{\mathrm{c} 1}$ and furnace walls $\mathrm{q}_{\mathrm{c} 2}$ at time $\mathrm{t}=\mathrm{j} \Delta \mathrm{t}$, is given as:

$\mathrm{q}_{\mathrm{c} 1}^{\mathrm{j}}=\mathrm{h}_{\mathrm{c} 1}\left[\mathrm{~T}_{\mathrm{g}}^{\mathrm{j}}-\left(\mathrm{T}_{1}\right)_{0}^{\mathrm{j}}\right]$

$\mathrm{q}_{\mathrm{c} 2}^{\mathrm{j}}=\mathrm{h}_{\mathrm{c} 2}\left[\mathrm{~T}_{\mathrm{g}}^{\mathrm{j}}-\left(\mathrm{T}_{2}\right)_{0}^{\mathrm{j}}\right]$

where $\left(T_{1}\right)_{0}$ is the exposed surface temperature of the specimen, $\left(T_{2}\right)_{0}$ is the exposed surface temperature of the furnace walls, $T_{g}$ is the furnace gas temperature, $h_{c 1}$ is the convective heat transfer coefficient for the specimen exposed surface, $h_{\mathrm{c} 2}$ is the convective heat transfer coefficient for the furnace wall surfaces [8].

The total heat absorbed by the specimen $q_{1}$ and by the furnace walls $q_{2}$ at time $t=j \Delta t$, is given as:

$\mathrm{q}_{1}^{\mathrm{j}}=\mathrm{q}_{\mathrm{r} 1}^{\mathrm{j}}+\mathrm{q}_{\mathrm{c} 1}^{\mathrm{j}}$

$q_{2}^{j}=q_{r 2}^{j}+q_{c 2}^{j}$

The exposed surface temperatures for the specimen and furnace walls were calculated at time $t=(j+1) \Delta t$ using the equations:

$$
\begin{aligned}
& \left(\mathrm{T}_{1}\right)_{0}^{\mathrm{j}+1}=\left(\mathrm{T}_{1}\right)_{0}^{\mathrm{j}}+\frac{2 \Delta \mathrm{t}}{\rho_{1} \mathrm{c}_{1} \Delta \mathrm{x}_{1}}\left\{\mathrm{q}_{1}^{\mathrm{j}}-\frac{\mathrm{k}_{1}}{\Delta \mathrm{x}_{1}}\left[\left(\mathrm{~T}_{1}\right)_{0}^{\mathrm{j}}-\left(\mathrm{T}_{1}\right)_{1}^{\mathrm{j}}\right]\right\} \\
& \left(\mathrm{T}_{2}\right)_{0}^{\mathrm{j}+1}=\left(\mathrm{T}_{2}\right)_{0}^{\mathrm{j}}+\frac{2 \Delta \mathrm{t}}{\rho_{2} \mathrm{c}_{2} \Delta \mathrm{x}_{2}}\left\{\mathrm{q}_{2}^{\mathrm{j}}-\frac{\mathrm{k}_{2}}{\Delta \mathrm{x}_{2}}\left[\left(\mathrm{~T}_{2}\right)_{0}^{\mathrm{j}}-\left(\mathrm{T}_{2}\right)_{1}^{\mathrm{j}}\right]\right\}
\end{aligned}
$$

where $\left(T_{1}\right)_{0}$ is the exposed specimen surface temperature, $\left(T_{2}\right)_{0}$ is the furnace exposed wall surface temperature; $\rho_{1}, c_{1}$ and $k_{1}$ are the density, specific heat and thermal conductivity of the specimen material, respectively; $\rho_{2}, c_{2}$ and $k_{2}$ are the density, specific heat and thermal conductivity of the furnace wall material, respectively; $\Delta \mathrm{t}$ is the time increment and $\Delta \mathrm{x}_{1}, \Delta \mathrm{x}_{2}$ are the element thicknesses in the specimen and furnace walls, respectively.

The equations describing the temperature distribution in the test specimen and the furnace walls are given by:

$$
\begin{aligned}
& \left(\mathrm{T}_{1}\right)_{\mathrm{i}}^{\mathrm{j}+1}=\left(\mathrm{T}_{1}\right)_{\mathrm{i}}^{\mathrm{j}}+\frac{\mathrm{k}_{1} \Delta \mathrm{t}}{\rho_{1} \mathrm{c}_{1} \Delta \mathrm{x}_{1}^{2}}\left[\left(\mathrm{~T}_{1}\right)_{\mathrm{i}-1}^{\mathrm{j}}-2\left(\mathrm{~T}_{1}\right)_{\mathrm{i}}^{\mathrm{j}}+\left(\mathrm{T}_{1}\right)_{\mathrm{i}+1}^{\mathrm{j}}\right] \\
& \left(\mathrm{T}_{2}\right)_{\mathrm{i}}^{\mathrm{j}+1}=\left(\mathrm{T}_{2}\right)_{\mathrm{i}}^{\mathrm{j}}+\frac{\mathrm{k}_{2} \Delta \mathrm{t}}{\rho_{2} \mathrm{c}_{2} \Delta \mathrm{x}_{2}^{2}}\left[\left(\mathrm{~T}_{2}\right)_{\mathrm{i}-1}^{\mathrm{j}}-2\left(\mathrm{~T}_{2}\right)_{\mathrm{i}}^{\mathrm{j}}+\left(\mathrm{T}_{2}\right)_{\mathrm{i}+1}^{\mathrm{j}}\right]
\end{aligned}
$$


where $\mathrm{i}=1,2, \ldots ., \mathrm{n}-1$ ( $\mathrm{n}-1$ is the number of points inside the specimen and inside the furnace walls).

The unexposed surface temperature for the specimen was calculated at a time $t=(j+1) \Delta t$, using the equation:

$$
\left(\mathrm{T}_{1}\right)_{\mathrm{n}}^{\mathrm{j}+1}=\left(\mathrm{T}_{1}\right)_{\mathrm{n}}^{\mathrm{j}}+\frac{2 \Delta \mathrm{t}}{\rho_{1} \mathrm{c}_{1} \Delta \mathrm{x}_{1}^{2}}\left\{\mathrm{k}_{1}\left[\left(\mathrm{~T}_{1}\right)_{\mathrm{n}-1}^{\mathrm{j}}-\left(\mathrm{T}_{1}\right)_{\mathrm{n}}^{\mathrm{j}}\right]-\mathrm{h}_{\mathrm{c} 0} \Delta \mathrm{x}_{1}\left[\left(\mathrm{~T}_{1}\right)_{\mathrm{n}}^{\mathrm{j}}-\left(\mathrm{T}_{0}\right)\right]-\sigma \varepsilon \Delta \mathrm{x}_{1}\left[\left(\mathrm{~T}_{1}\right)_{\mathrm{n}}^{\mathrm{j}}{ }^{4}-\left(\mathrm{T}_{0}\right)^{4}\right]\right\}
$$

where $\mathrm{hc}_{0}, \mathrm{~T}_{0}$ and $\varepsilon$ are the heat transfer coefficient, the air temperature at the ambient side and the specimen unexposed surface emissivity, respectively.

Equations (1) to (13) along with equations (8), (9) and (12) to (32) in Reference [6] were solved using the method described in References [5] and [6] to determine the heat absorbed by the specimen and the temperature inside the test specimen $40 \mathrm{~mm}$ from the fire exposed surface.

\section{EXPERIMENTAL WORK}

Sixteen fire resistance tests were conducted with a castable refractory brick specimen, 152 $\mathrm{mm}$ thick. Eight tests were conducted with the furnace lined with ceramic fibre insulation and another eight tests were conducted with the furnace lined with insulating firebrick.

The tests were carried out by exposing the test specimen to heat in a full-scale propane-fired floor furnace, $4870 \mathrm{~mm}$ long by $3962 \mathrm{~mm}$ wide by $2438 \mathrm{~mm}$ deep. The furnace temperature was measured by nine shielded thermocouples in accordance with CAN/ULC-S101-M89. The average temperature of these nine thermocouples was used to control the furnace. The temperature inside the test specimen $40 \mathrm{~mm}$ from the exposed surface was measured at 5 locations: one at the centre and one at the centre of each of the quarter sections. The average temperature distribution in the test specimen ( 8 tests) for the furnace lined with ceramic fibre insulation is shown in Figure 1 and, for the furnace lined with insulating firebrick, in Figure 2.

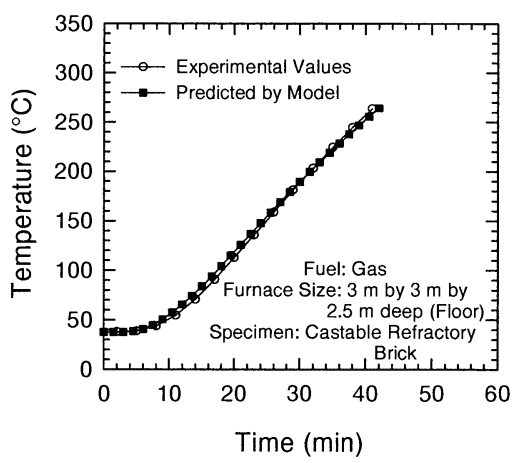

FIGURE 1. Temperature History $40 \mathrm{~mm}$ Above Exposed Surface of Specimen, Furnace Lined with Ceramic Fibre Insulation.

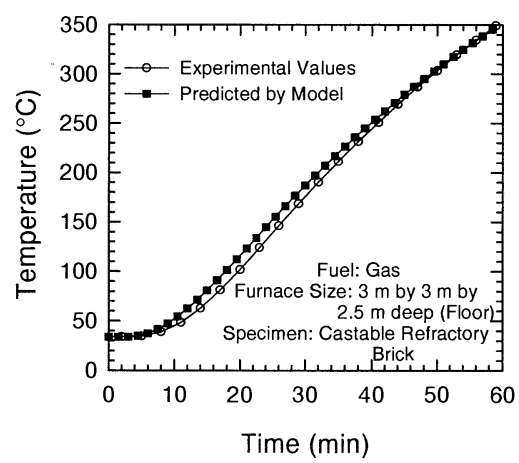

FIGURE 2. Temperature History $40 \mathrm{~mm}$ Above Exposed Surface of Specimen, Furnace Lined with Insulating Firebrick 


\section{COMPARISON OF MODEL AND EXPERIMENTAL RESULTS}

To validate the mathematical models presented above, comparisons were made between the predicted and average measured temperatures inside a specimen $40 \mathrm{~mm}$ from the fireexposed side in furnaces lined with ceramic fibre insulation and with insulating firebrick. The results are presented in Figures 1 and 2, respectively. Temperature predictions are in good agreement with the measured temperatures.

\section{RESULTS OF THEORETICAL STUDIES}

The input variables used in this study are presented in Table 1. Two furnace sizes were considered: one was $3 \mathrm{~m}$ long by $3 \mathrm{~m}$ wide by $2.5 \mathrm{~m}$ deep and the other was $3 \mathrm{~m}$ high by $3 \mathrm{~m}$ wide by $0.5 \mathrm{~m}$ deep representing typical floor and wall furnaces, respectively. The absorption coefficient for the furnace hot gases, $\alpha$, was assumed to be 0.2 for furnaces heated with pre-mixed gas fuels (propane and natural gas) and 1.6 for furnaces heated with liquid fuels [5] (gasoline).

The properties of the castable refractory brick (marketed as "KS-4") and lightweight concrete are given in Table 1. These materials were used to simulate a test specimen. The furnace walls were assumed to be either fireclay, insulating firebrick or ceramic fibre insulation. The properties of these materials are given in Table 1.

TABLE 1. Input Variables Used in the Theoretical Studies.

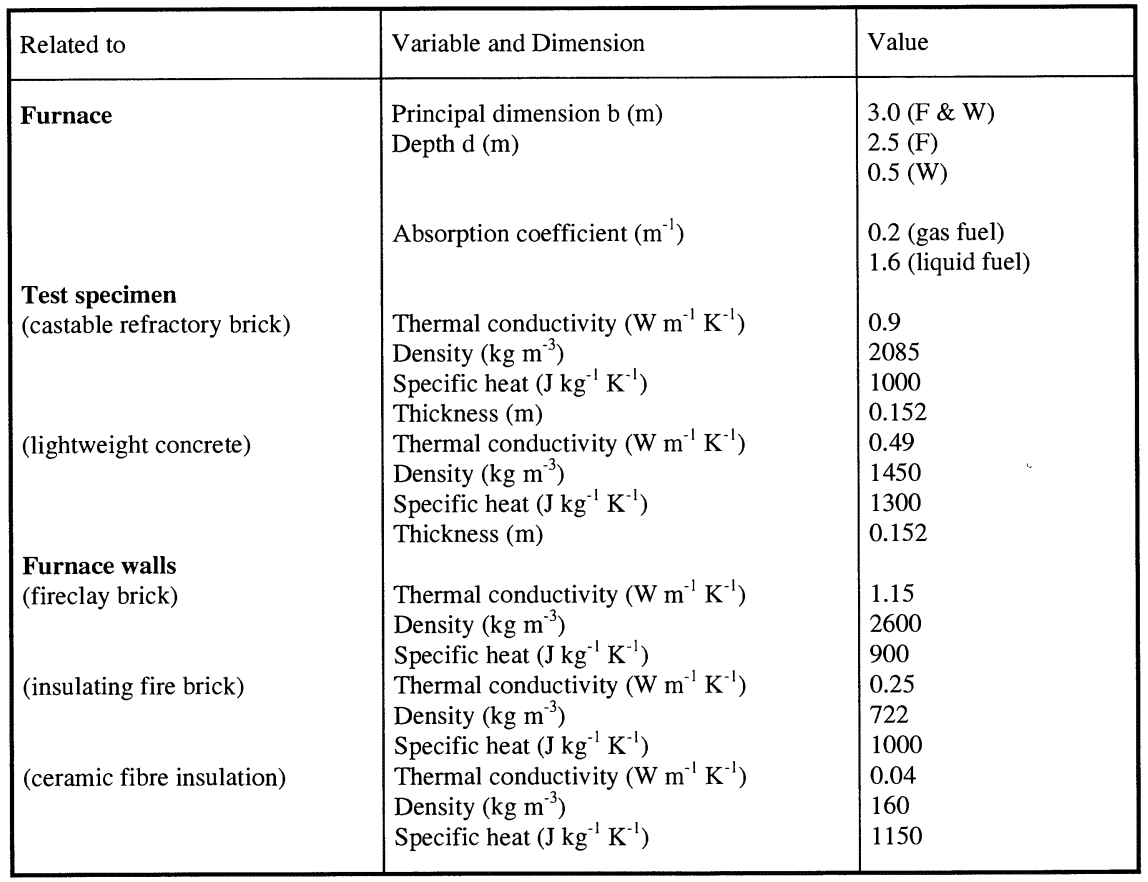

F - Floor Furnace W - Wall Furnace 


\section{Furnace Lining}

To study the effect of the furnace wall lining materials on the fire severity in fire resistance test furnaces, simulations were carried out using $152 \mathrm{~mm}$ thick castable refractory brick and $152 \mathrm{~mm}$ thick lightweight concrete specimens exposed to heat for 2 hours in a pre-mixed gas heated floor furnace lined with different materials (fireclay brick, insulating firebrick and ceramic fibre insulation). The predicted results are presented in Figures 3-6. Figures 3 and 5 show the heat absorbed by a castable refractory brick specimen and by a lightweight concrete specimen, respectively in furnaces controlled by the CAN/ULC-S101/ASTM E119 timetemperature relationship. Figures 4 and 6 show the heat absorbed by a castable refractory brick specimen and by a lightweight concrete specimen, respectively in furnaces controlled by the ISO 834 time-temperature relationship.

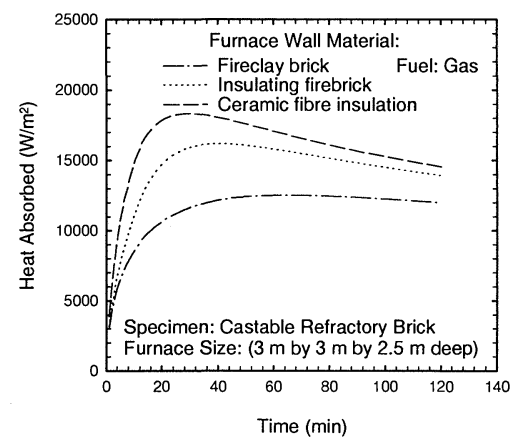

FIGURE 3. Heat Absorbed by Specimen Using CAN/ULC-S101/ASTM E119 TimeTemperature Relationship in Floor Furnace with Different Lining Materials

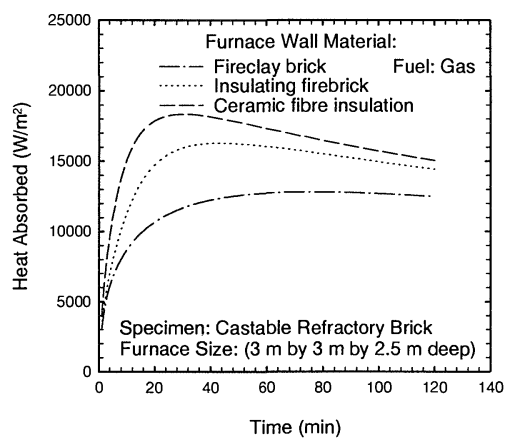

FIGURE 4. Heat Absorbed by Specimen Using ISO 834 Time-Temperature Relationship in Floor Furnace with Different Lining Materials

As shown in Figures 3-6, the heat absorbed by the specimen is dependant on the furnace lining material type. In furnaces heated with pre-mixed gas (clean burning), the test specimen receives radiative heat from both the hot gases and the furnace walls provided the furnace wall temperature is higher than the specimen exposed surface temperature (furnace wall material has a lower thermal conductivity than the specimen). If the furnace wall temperature is lower than the specimen exposed surface temperature (furnace wall has a relatively higher thermal conductivity than the specimen), then the specimen receives heat by radiation from the hot gases and loses heat by radiation to the furnace walls.

The total heat absorbed by a specimen during a $2 \mathrm{~h}$ fire exposure in a furnace lined with ceramic fibre insulation, insulating fire brick and fireclay brick is presented in Table 2. These results show that, for a furnace heated with pre-mixed gas for 2 hours using CAN/ULC-S101, ASTM E119 and ISO 834 time-temperature relationships, the total heat absorbed by a specimen for a furnace lined with fireclay brick or insulating firebrick compared to the heat absorbed by a specimen in a furnace lined with ceramic fibre insulation were $71 \%$ and $90 \%$, respectively, for a castable refractory brick specimen and $73 \%$ and $90 \%$, respectively, for a lightweight concrete specimen. When the furnace is lined with a low thermal conductivity material such as ceramic fibre insulation, the heat loss through the furnace walls is lower than in the case where the furnace is lined with either fireclay brick or insulating fire brick. Consequently, the temperature of the furnace wall is closer to the furnace gas temperature. 


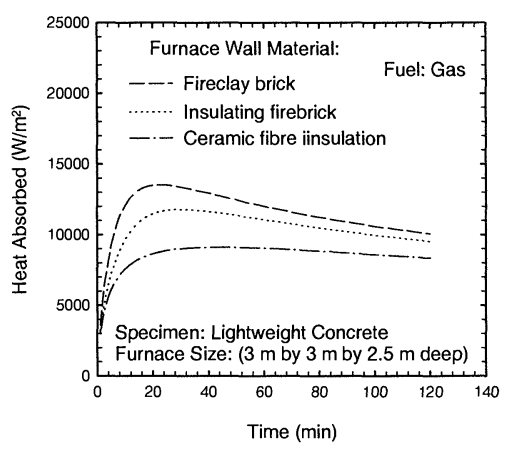

FIGURE 5. Heat Absorbed by Specimen Using CAN/ULC-S101/ASTM E119 TimeTemperature Relationship in Floor Furnace with Different Lining Materials

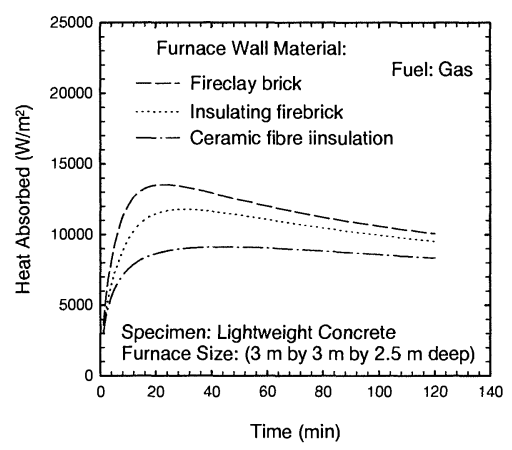

FIGURE 6. Heat Absorbed by Specimen Using ISO 834 Time-Temperature Relationship in Floor Furnace with Different Lining Materials

TABLE 2. Effect of Furnace Lining Materials on Heat Absorbed by a Specimen.

\begin{tabular}{|c|c|c|c|c|c|}
\hline \multirow{3}{*}{ Furnace Wall Lining } & \multirow{3}{*}{ Fuel } & \multicolumn{4}{|c|}{ Total Heat Absorbed $\left(\mathrm{kJ} / \mathrm{m}^{2}\right)$ in $2 \mathrm{~h}$ Fire Exposure } \\
\hline & & \multicolumn{2}{|c|}{$\begin{array}{l}\text { CAN/ULC-S101, } \\
\text { ASTM E119 }\end{array}$} & \multicolumn{2}{|c|}{ ISO 834} \\
\hline & & $\begin{array}{l}\text { Castable } \\
\text { Refractory } \\
\text { Brick }\end{array}$ & $\begin{array}{l}\text { Lightweight } \\
\text { Concrete }\end{array}$ & $\begin{array}{l}\text { Castable } \\
\text { Refractory } \\
\text { Brick } \\
\end{array}$ & $\begin{array}{l}\text { Lightweight } \\
\text { Concrete }\end{array}$ \\
\hline Ceramic Fibre Insulation & Gas & 112,492 & 81,152 & 114,399 & 82,467 \\
\hline Insulating Firebrick & Gas & 101,127 & 73,094 & 102,923 & 74,428 \\
\hline Fireclay Brick & Gas & 80,285 & 59,596 & 81,936 & 59,988 \\
\hline
\end{tabular}

The results of the simulations indicate that, in furnaces heated with pre-mixed gas, the furnace wall lining material has a significant role in the heat absorbed by the specimen. Thus, specimens tested in furnaces heated with pre-mixed gas using the same timetemperature relationship but with different wall lining materials will receive different fire exposures and will achieve significantly different fire resistance ratings.

\section{Furnace Fuel}

To study the effect of fuel type on the fire severity in fire resistance test furnaces, simulations were carried out using $152 \mathrm{~mm}$ thick castable refractory brick and $152 \mathrm{~mm}$ thick lightweight concrete specimens exposed to heat for $2 \mathrm{~h}$ in four floor furnaces as follows: (1) a furnace heated with pre-mixed gas fuel and with walls lined with ceramic fibre insulation, (2) a furnace heated with liquid fuel and with walls lined with ceramic fibre insulation, (3) a furnace heated with liquid fuel and with walls lined with fireclay brick and (4) a furnace heated with liquid fuel and with walls lined with insulating firebrick. The predicted results 
for the heat absorbed by castable refractory brick specimen and by lightweight concrete specimen are shown in Figures 7-10.

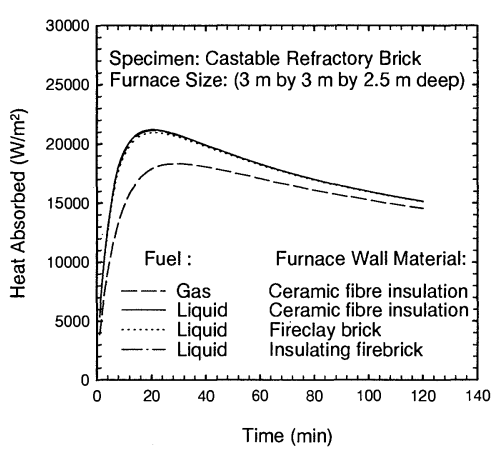

FIGURE 7. Heat Absorbed by Specimen Using CAN/ULC-S101/ASTM E119 TimeTemperature Relationship and Floor Furnace Heated with Different Fuels and Lined with Different Materials

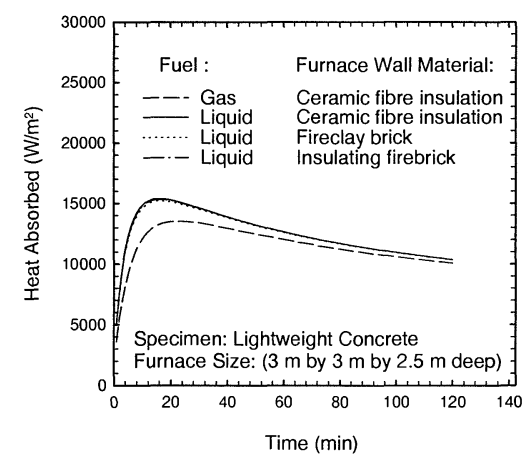

FIGURE 9. Heat Absorbed by Specimen Using CAN/ULC-S101/ASTM E119 TimeTemperature Relationship and Floor Furnace Heated with Different Fuels and Lined with Different Materials

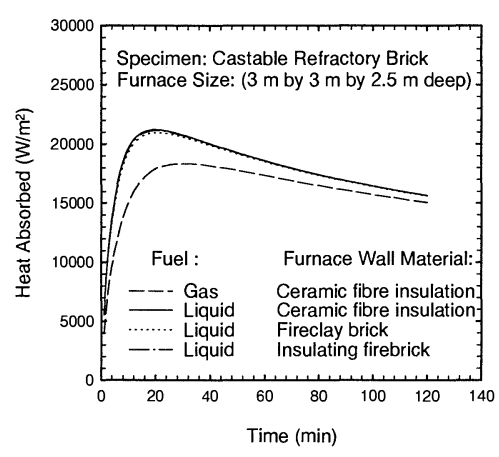

FIGURE 8. Heat Absorbed by Specimen Using ISO 834 Time-Temperature Relationship and Floor Furnace Heated with Different Fuels and Lined with Different Materials

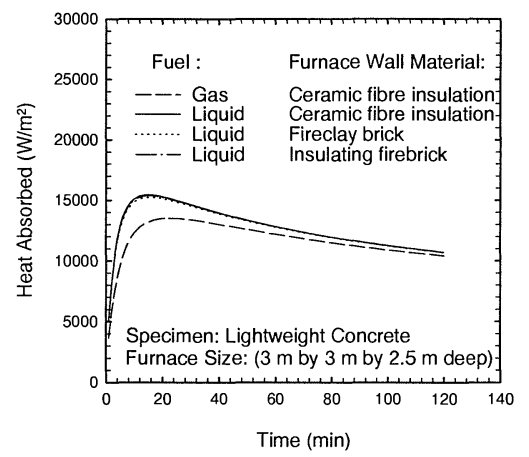

FIGURE 10. Heat Absorbed by Specimen Using ISO 834 TimeTemperature Relationship and Floor Furnace Heated with Different Fuels and Lined with Different Materials

Figures 7 and 9 show the heat absorbed by a castable refractory brick specimen and by a lightweight concrete specimen in furnaces controlled by the CAN/ULC-S101/ASTM E119 time-temperature relationship. Figures 8 and 10 show the heat absorbed by a castable refractory brick specimen and by a lightweight concrete specimen in furnaces controlled by the ISO 834 time-temperature relationship. The total heat absorbed by a specimen during a 2 $\mathrm{h}$ fire exposure is presented in Table 3. The heat absorbed by the specimen in a furnace 
heated with pre-mixed gas fuel and lined with ceramic fibre insulation is slightly lower (9\% for castable refractory brick specimen and $8 \%$ for lightweight concrete specimen) than for the other furnaces heated by liquid fuel.

TABLE 3. Effect of Furnace Fuel on Heat Absorbed by a Specimen.

\begin{tabular}{|c|c|c|c|c|c|}
\hline \multirow{3}{*}{ Furnace Wall Lining } & \multirow{3}{*}{ Fuel } & \multicolumn{4}{|c|}{ Total Heat Absorbed $\left(\mathrm{kJ} / \mathrm{m}^{2}\right)$ in $2 \mathrm{~h}$ Fire Exposure } \\
\hline & & \multicolumn{2}{|c|}{$\begin{array}{l}\text { CAN/ULC-S101, } \\
\text { ASTM E119 }\end{array}$} & \multicolumn{2}{|c|}{ ISO 834} \\
\hline & & $\begin{array}{l}\text { Castable } \\
\text { Refractory } \\
\text { Brick }\end{array}$ & $\begin{array}{l}\text { Lightweight } \\
\text { Concrete }\end{array}$ & $\begin{array}{l}\text { Castable } \\
\text { Refractory } \\
\text { Brick }\end{array}$ & $\begin{array}{l}\text { Lightweight } \\
\text { Concrete }\end{array}$ \\
\hline Ceramic Fibre Insulation & Gas & 112,492 & 81,152 & 114,399 & 82,467 \\
\hline Ceramic Fibre Insulation & Liquid & 124,707 & 88,009 & 126,766 & 89,414 \\
\hline Fireclay Brick & Liquid & 123,794 & 87,404 & 125,843 & 88,803 \\
\hline Insulating Fire Brick & Liquid & 124,425 & 87,818 & 126,481 & 89,221 \\
\hline
\end{tabular}

In a pre-mixed gas heated furnace, the specimen sees and receives radiative heat from both the hot gases and the furnace walls lined with ceramic fibre insulation while in liquid fuel heated furnaces, the specimen sees and receives most of the radiative heat from the luminous flames.

These results indicate that the effect of the type of fuel used on the fire exposure severity is insignificant provided that the furnace is lined with ceramic fibre insulation.

\section{Furnace Depth}

To study the effect of furnace depth $(2.5 \mathrm{~m}$ versus $0.5 \mathrm{~m})$ on the fire severity in fire test furnaces, simulations were carried out using a $152 \mathrm{~mm}$ thick castable refractory brick specimen and a $152 \mathrm{~mm}$ thick lightweight concrete specimen exposed to heat for $2 \mathrm{~h}$ in two furnaces lined with ceramic fibre insulation: one $2.5 \mathrm{~m}$ deep and the other $0.5 \mathrm{~m}$ deep. In both cases, the furnaces were heated using pre-mixed gas. The predicted results for the heat absorbed by a specimen are shown in Figures 11-14. Figures 11 and 13 show the heat absorbed by a castable refractory brick specimen and by a lightweight concrete specimen in furnaces controlled by the CAN/ULC-S101/ASTM E119 time-temperature relationship. Figures 12 and 14 show the heat absorbed by a castable refractory brick specimen and by a lightweight concrete specimen in furnaces controlled by the ISO 834 time-temperature relationship. The total heat absorbed by a specimen during a $2 \mathrm{~h}$ fire exposure is given in Table 4 . The heat absorbed by a castable refractory specimen and by a lightweight concrete specimen in a $0.5 \mathrm{~m}$ deep furnace are approximately 6-8\% lower than the heat absorbed by similar specimens in a $2.5 \mathrm{~m}$ deep furnace. These results suggest that the effect of furnace depth on the fire exposure severity is insignificant provided the furnace is lined with ceramic fibre insulation. 


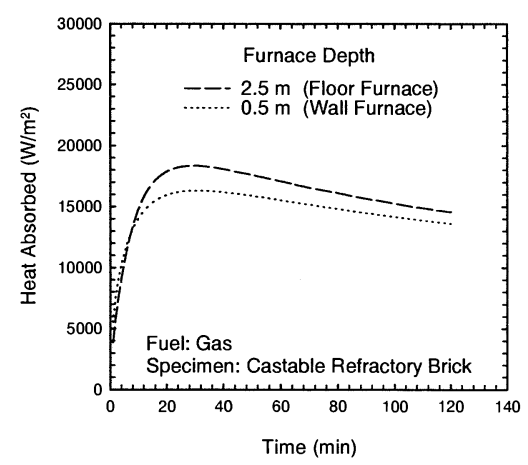

FIGURE 11. Heat Absorbed by Specimen Using CAN/ULC-S101/ASTM E119 TimeTemperature Relationship and Wall and Floor Furnaces Lined with Ceramic Fibre Insulation

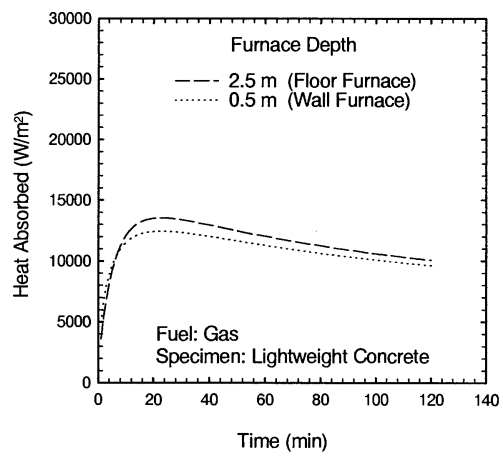

FIGURE 13. Exposed Surface Temperature FIGURE 14. Unexposed Surface of Specimen Using CAN/ULC-S101/ASTM E119 Time-Temperature Relationship and Wall and Floor Furnaces Lined with Ceramic Fibre Insulation

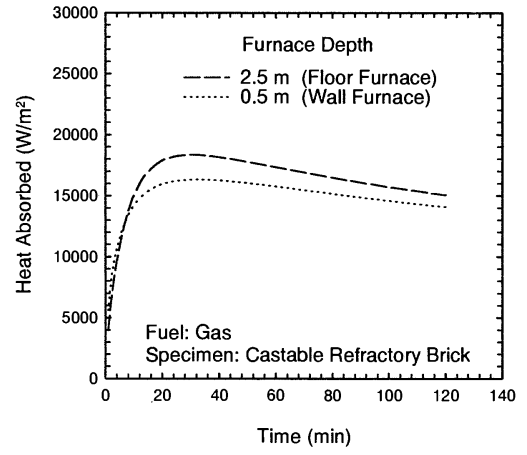

FIGURE 12. Heat Absorbed by Specimen Using ISO 834 TimeTemperature Relationship and Wall and Floor Furnaces Lined with Ceramic Fibre Insulation

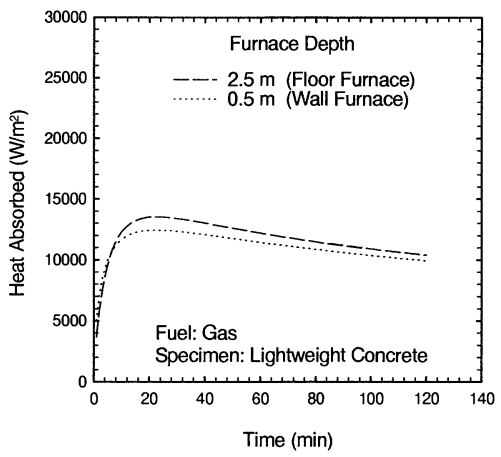

Temperature of Specimen Using ISO 834

Time-Temperature Relationship and Wall and Floor Furnaces Lined with Ceramic Fibre Insulation 
TABLE 4. Effect of Furnace Depth on Heat Absorbed by a Specimen.

\begin{tabular}{|l|l|l|l|l|l|l|}
\hline \multirow{2}{*}{$\begin{array}{l}\text { Furnace Wall } \\
\text { Lining }\end{array}$} & $\begin{array}{l}\text { Furnace } \\
\text { Depth } \\
(\mathrm{m})\end{array}$ & Fuel & & \multicolumn{4}{|l|}{\begin{tabular}{l} 
Total Heat Absorbed $\left(\mathrm{kJ} / \mathrm{m}^{2}\right)$ in 2 h Fire Exposure \\
\cline { 4 - 7 }
\end{tabular}} & $\begin{array}{l}\text { CAN/ULC-S101, } \\
\text { ASTM E119 }\end{array}$ & \multicolumn{2}{l|}{$\begin{array}{l}\text { ISO } 834 \\
\text { Castable } \\
\text { Refractory } \\
\text { Brick }\end{array}$} & $\begin{array}{l}\text { Lightweight } \\
\text { Concrete }\end{array}$ & $\begin{array}{l}\text { Castable } \\
\text { Refractory } \\
\text { Brick }\end{array}$ & $\begin{array}{l}\text { Lightweight } \\
\text { Concrete }\end{array}$ \\
\hline $\begin{array}{c}\text { Ceramic Fibre } \\
\text { Insulation }\end{array}$ & 2.5 & Gas & 112,492 & 81,152 & 114,399 & 82,467 \\
\hline $\begin{array}{c}\text { Ceramic Fibre } \\
\text { Insulation }\end{array}$ & 0.5 & Gas & 103,359 & 76,612 & 105,062 & 77,811 \\
\hline
\end{tabular}

\section{CONCLUSIONS}

This paper discussed the effects of furnace lining material, type of fuel and furnace depth on the fire severity in standard fire resistance test methods. The model used was validated as the predicted temperatures in the specimen, $40 \mathrm{~mm}$ from the exposed surface, are in good agreement with the measured temperatures. The predicted results indicate:

1. For furnaces heated with pre-mixed gas fuels, the furnace lining material has a significant effect (up to $30 \%$ ) on the heat severity received by the specimen.

2. For fire resistance test furnaces lined with ceramic fibre insulation, the effect of fuel type on the fire severity is insignificant (approximately 9\%).

3. For fire resistance test furnaces lined with ceramic fibre insulation, the effect of the furnace depth on the fire severity is insignificant (approximately $8 \%$ ).

The results of this study suggest that if a fire resistance test furnace is lined with low thermal conductivity materials, such as ceramic fibre insulation, the test results produced by furnaces heated with liquid and gas fuels or furnaces with different depths should be comparable.

Based on the results mentioned above, standards writing organizations such as ULC, ASTM and ISO should consider specifying the furnace lining material in fire resistance test methods to ensure that fire resistance test specimens in different testing laboratories using different fuels or different furnace depths will be exposed to similar fire severities.

The results of this study indicate that low conductivity materials, such as ceramic fibre insulation, can be used as a furnace lining to achieve better harmonization of fire severity in fire resistance test furnaces.

\section{REFERENCES}

1. Cooke, G.M.E., "Can Harmonisation of Fire Resistance Furnaces be Achieved by Plate Thermometer Control?", Proceedings of the Fourth International Symposium on Fire Safety Science, Ottawa, Canada, 1994.

2. ISO 834, Fire-Resistance Tests - Elements of Building Construction, International Standards Organization, Geneva, Switzerland, 1975.

3. CAN/ULC-S101-M89, Standard Methods of Fire Endurance Tests of Building Construction and Materials, Underwriters' Laboratories of Canada, Scarborough, Ontario, Canada, 1989.

4. ASTM E119-88, Standard Methods of Fire Tests of Building Constructions and Materials, American Society for Testing and Materials, Philadelphia, PA, 1995. 
5. Harmathy, T.Z., "The Fire Resistance Test and its Relation to Real-World Fires", Fire and Materials, 5: 3, 112-122, 1981.

6. Sultan, M.A., Harmathy, T.Z. and Mehaffey, J.R., "Heat Transmission in Fire Test Furnaces", Fire and Materials, 10: 2, 47-55, 1986.

7. Sultan, M.A., "The Effect of Furnace Parameters on the Fire Severity in Standard Fire Resistance Tests", Fire and Materials, 20: 5, 245-252, 1996.

8. Technical Data on Fuel, ed. H. M. Spiers, 4th Edition, British National Committee, World Power Conference, London, 1943. 